\title{
Article \\ Chemical Composition of Essential Oil from Flowers of Five Fragrant Dendrobium (Orchidaceae)
}

\author{
Francesco Saverio Robustelli della Cuna ${ }^{1,2, *(\mathbb{D})}$, Jacopo Calevo $\left.{ }^{3, *} \mathbb{(}\right)$, Miriam Bazzicalupo ${ }^{4}\left(\mathbb{D}\right.$, Cristina Sottani ${ }^{5}(\mathbb{D}$, \\ Elena Grignani ${ }^{5}$ and Stefania Preda ${ }^{1}$ \\ 1 DDS-Department of Drug Sciences, University of Pavia, 27100 Pavia, Italy; stefania.preda@unipv.it \\ 2 Casimiro Mondino National Neurological Institute, 27100 Pavia, Italy \\ 3 DBIOS-Department of Life Sciences and Systems Biology, University of Torino, 10125 Torino, Italy \\ 4 DISTAV-Department of Earth, Environment and Life Sciences, University of Genova, 16132 Genova, Italy; \\ miriam.bazzicalupo@gmail.com \\ 5 Environmental Research Center, ICS MAUGERI SPA SB, Institute of Pavia, IRCCS, 27100 Pavia, Italy; \\ cristina.sottani@icsmaugeri.it (C.S.); elena.grignani@icsmaugeri.it (E.G.) \\ * Correspondence: fsaveriorobustelli@unipv.it (F.S.R.d.C.); jacopo.calevo@unito.it (J.C.)
}

check for

updates

Citation: Robustelli della Cuna, F.S.; Calevo, J.; Bazzicalupo, M.;

Sottani, C.; Grignani, E.; Preda, S.

Chemical Composition of Essential

Oil from Flowers of Five Fragrant Dendrobium (Orchidaceae). Plants 2021, 10, 1718. https://doi.org/ $10.3390 /$ plants10081718

Academic Editors: Cecilia Cagliero, Barbara Sgorbini and Patrizia Rubiolo

Received: 21 June 2021

Accepted: 18 August 2021

Published: 20 August 2021

Publisher's Note: MDPI stays neutral with regard to jurisdictional claims in published maps and institutional affiliations.

Copyright: (c) 2021 by the authors. Licensee MDPI, Basel, Switzerland. This article is an open access article distributed under the terms and conditions of the Creative Commons Attribution (CC BY) license (https:// creativecommons.org/licenses/by/ $4.0 /)$.

\begin{abstract}
A detailed chemical composition of Dendrobium essential oil has been only reported for a few main species. This article is the first to evaluate the essential oil composition, obtained by steam distillation, of five Indian Dendrobium species: Dendrobium chrysotoxum Lindl., Dendrobium harveyanum Rchb.f., and Dendrobium wardianum R.Warner (section Dendrobium), Dendrobium amabile (Lour.) O'Brien, and Dendrobium chrysanthum Wall. ex Lindl. (section Densiflora). We investigate fresh flower essential oil obtained by steam distillation, by GC/FID and GC/MS. Several compounds are identified, with a peculiar distribution in the species: Saturated hydrocarbons (range 2.19-80.20\%), organic acids (range 0.45-46.80\%), esters (range 1.03-49.33\%), and alcohols (range 0.12-22.81\%). Organic acids are detected in higher concentrations in D. chrysantum, D. wardianum, and D. harveyanum $(46.80 \%$, $26.89 \%$, and $7.84 \%$, respectively). This class is represented by palmitic acid $(13.52 \%, 5.76$, and $7.52 \%)$ linoleic acid (D. wardianum 17.54\%), and (Z)-11-hexadecenoic acid (D. chrysantum $29.22 \%$ ). Esters are detected especially in species from section Dendrobium, with ethyl linolenate, methyl linoleate, ethyl oleate, and ethyl palmitate as the most abundant compounds. Alcohols are present in higher concentrations in D. chrysantum (2.4-di-tert-butylphenol, 22.81\%), D. chrysotoxum (1-octanol, and 2-phenylethanol, 2.80\% and 2.36\%), and D. wardianum (2-phenylethanol, 4.65\%). Coumarin (95.59\%) is the dominant compound in D. amabile (section Densiflora) and detected in lower concentrations (range $0.19-0.54 \%$ ) in other samples. These volatile compounds may represent a particular feature of these plant species, playing a critical role in interacting with pollinators.
\end{abstract}

Keywords: Dendrobium; essential oil; steam distillation; mass spectrometry; pollinator

\section{Introduction}

The Orchidaceae family, with its huge number of species that evolved different pollination systems, is known for the variety and complexity of its floral scents, which according to Kaiser (1993), could potentially cover all the spectrum of fragrances occurring in nature [1]. Floral scent, which derives from the composition of volatile organic compounds emitted by the flowers' tissues (floral VOCs), is fundamental for the defense against pathogens/herbivores and pollinator responses [2]. This trait, together with other characteristics of flowers, such as the color, the presence of nectar, and other peculiarities of the reproductive portions, contributes indeed to defining pollination syndromes [3]. The genus Dendrobium Sw., 1799 (Epidendroideae; Dendrobiinae), which accounts for about 1100 species distributed in Pacific Islands, Asia, and Australia, is one of the largest of the family [4]. As potted and cut flowers, Dendrobium species and hybrids are of great economic interest, being at the top ten among the most commercially traded orchid taxa [5]; several species are also 
grown and sold for medicinal purposes [6,7]. A large number of taxa, the great morphological diversity, and the wide distribution range have contributed to taxonomic ambiguities that are currently under debate $[4,8,9]$. In the phylogenetic revision of the genus, Takamiya et al. (2014) considered the presence of papillae on the flower's lip in entities belonging to different clades. They demonstrated that this character evolved as an adaptation to bee pollination by Dendrobium species [4]. As stated in previous studies, bee-pollinated orchid flowers exhibit papillose carpets, identified as osmophores, structures of accumulation of substances responsible for floral fragrances [10,11]. Takamiya et al. (2014) recorded odorproducing cells in all species of Section Densiflora and the majority of the Section Dendrobium, thus hypothesizing that this character has probably been acquired after the divergence between the Asian and the Australasian Superclades [4]. Despite the great number of studies aimed at optimizing in vitro propagation protocols (i.e., Marting and Madassery, 2006; Teixera da Silva et al., 2015; Calevo et al. 2020; and references therein) [12-14], and at characterizing anatomical and chemical traits (Carlsward et al., 1997; Xu et al., 2013; Devadas et al., 2016 and references therein) [15-17], the genus Dendrobium has been little investigated from the point of view of the reproductive biology, and even less is known about floral volatilome [18]. To the best of our knowledge, only a few authors had carried out characterizations of floral volatiles from Dendrobium species. Flath and Ohinata (1982) investigated the VOCs of D. superbum Rchb. f. (syn. D. anosmum Lindl.), which is pollinated by the melon fly (Dacus cucurbitae), finding a significant amount of 4-phenylbutan-2-one, whose structure is closely related to another known fly attractant [19]. Brodmann et al. (2009) worked on $D$. sinense Tang and F.T.Wang and reported that this species emits (Z)-11-eicosen-1-ol (a molecule present in the alarm pheromone of honeybees) to attract hornets for pollination [20]. Silva et al. (2015) recognized terpenes as the most abundant class of compounds in the floral volatiles of D. nobile Lindl. [21]. Julsrigival et al. (2013) found a prevalence of 2-pentadecanone in D. parishii Rchb.f. [22]. Robustelli della Cuna et al. (2017), instead, compared the essential oil of different portions of D. moschatum (Buch.-Ham.) Sw., including the inflorescence: They observed differences among the volatile compositions, and then hypothesized that compounds like ketones or long-chain methyl and ethyl esters play a role as pollinator attractants [23]. The few reports dedicated to reproductive biology have stated that there are various ways for which Dendrobium species attract pollinators: There are cases of shelter mimicry [24-28], nectar rewarding [18], chemical and visual attraction [29], rest and mating place offering, or generalized food deception strategies like a simulation of other co-flowering species occurring in the same habitat [30]. In this work, we aimed to characterize and compare the floral volatiles of five Dendrobiums belonging to sections Dendrobium and Densiflora of the Asian Superclade [4,9]. In particular, we characterized the volatile fractions of the inflorescences of $D$. chrysanthum Wall. ex Lindl. (Figure 1A), D. harveyanum Rchb. f. (Figure 1B) and D. wardianum R.Warner (Figure 1C) from section Dendrobium, Core subclade of Clade A, and D. chrysotoxum Lindl. (Figure 1D) and D. amabile (Lour.) O'Brien (Figure 1E) from Clade A and C, respectively, of section Densiflora (according to Takamiya et al. 2014) [4]. 


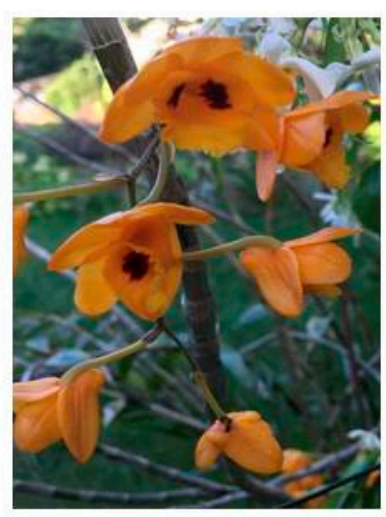

A

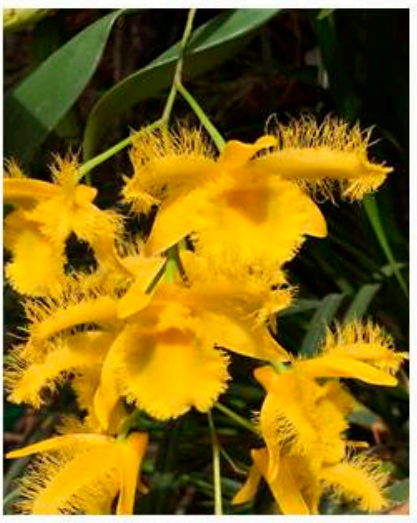

B

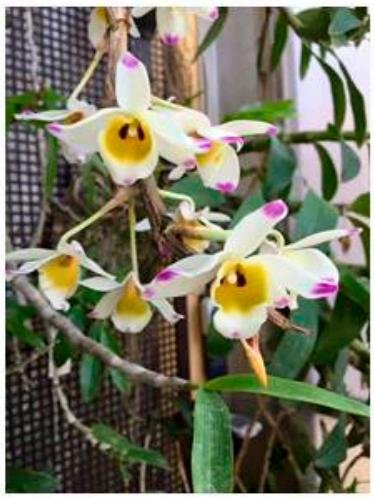

C

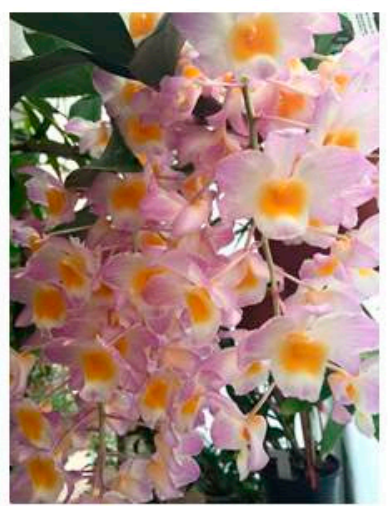

D

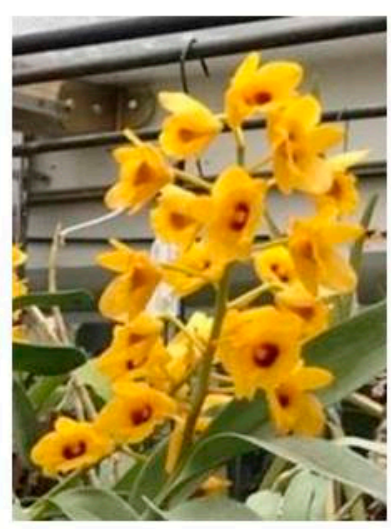

E

Figure 1. Dendrobium chrysanthum (A), D. harveyanum (B), D. wardianum (C), D. amabile (D), and D. chrysotoxum (E), greenhouse-grown plants cultivated in Turin (Italy).

\section{Results}

The yields of D. amabile, D. chrysanthum, D. chrysotoxum, D. harveyanum, and D. wardianum essential oils obtained by steam distillation from fresh flowers were evaluated as $0.09 \%$, $0.34 \%, 0.33 \%, 0.39 \%$, and $0.33 \%$ (weight/dry weight basis), respectively. Table 1 shows the results of qualitative and quantitative oil analyses on the Elite-5MS column. The compounds are listed in order of their elution and are reported as percentages of the total essential oil. Differences in the qualitative and quantitative compositions of the obtained essential oils have been observed. As shown in the Venn's diagram (Figure 2), only palmitic acid was shared by all five taxa. On the other hand, 30 compounds were uniquely identified in D. chrysotoxum, and nine, eight, four, and three in D. wardianum, D. harveyanum, D. chrysanthum, and D. amabile, respectively. Furthermore, 21 compounds were found shared by D. chrysotoxum and D. wardianum. Below, the qualitative and quantitative description of essential oils for each taxon. The Pie chart (Figure 3) shows that the essential oils were different depending on the different species: It can be observed that the main constituents were compounds belonging to saturated hydrocarbons, acids, esters, coumarin, and alcohol classes. 
Table 1. Essential oils composition of inflorescences from the five Dendrobium species.

\begin{tabular}{|c|c|c|c|c|c|c|c|c|}
\hline \multirow[b]{2}{*}{ Compound $^{\mathrm{a}}$} & \multirow[b]{2}{*}{$\mathbf{R I}^{\mathbf{b}}$} & \multirow[b]{2}{*}{$\mathbf{R I}^{\mathrm{c}}$} & \multirow[b]{2}{*}{$\begin{array}{c}\text { D. chrysotoxum } \\
\%\end{array}$} & \multirow{2}{*}{$\begin{array}{c}\text { Section Dendrobium } \\
\text { D. harvejanum } \\
\%\end{array}$} & \multirow[b]{2}{*}{$\begin{array}{c}\text { D. wardianum } \\
\%\end{array}$} & \multicolumn{2}{|c|}{ Section Densiflora } & \multirow[b]{2}{*}{ Identification } \\
\hline & & & & & & $\begin{array}{c}\text { D. amabile } \\
\%\end{array}$ & $\begin{array}{c}\text { D. chrysanthum } \\
\%\end{array}$ & \\
\hline Octane & 800 & 800 & - & 0.15 & - & - & - & RI, NIST \\
\hline 2-hexanol & 804 & 808 & - & 0.12 & - & - & - & RI, NIST \\
\hline Diacetone alcohol & 841 & 841 & - & - & - & - & 0.68 & RI, NIST \\
\hline$\alpha$-pinene & 939 & 931 & 0.21 & - & - & - & - & MS, NIST \\
\hline Benzaldehyde & 960 & 958 & 0.14 & - & - & - & - & RI, NIST \\
\hline Caproic acid & 1005 & 1003 & 0.06 & - & - & - & - & RI, NIST \\
\hline$\alpha$-terpinene & 1017 & 1015 & 0.10 & - & - & - & - & RI, NIST \\
\hline$o$-Cymene & 1026 & 1023 & 0.09 & - & - & - & - & RI, NIST \\
\hline Limonene & 1029 & 1027 & 0.17 & - & - & - & - & RI, NIST \\
\hline Benzyl alchol & 1032 & 1035 & 0.21 & - & 0.52 & - & - & RI, NIST \\
\hline$\beta$-Isophorone & 1042 & 1041 & 0.51 & - & & - & - & RI, NIST \\
\hline Phenylacetaldehyde & 1042 & 1043 & 0.84 & - & 0.06 & - & - & RI, NIST \\
\hline 2-octenal & 1056 & 1058 & - & 0.13 & - & - & 0.06 & RI, NIST \\
\hline$\gamma$-Terpinene & 1060 & 1059 & 0.76 & - & 0.04 & - & - & RI, NIST \\
\hline cis-sabinene hydrate & 1070 & 1067 & 0.27 & - & - & - & - & MS, NIST \\
\hline dihydromyrcenol & 1073 & 1073 & - & 0.04 & - & - & 0.06 & RI, NIST \\
\hline 1-octanol & 1070 & 1074 & 2.80 & - & 0.41 & - & - & MS, NIST \\
\hline trans-sabinene hydrate & 1098 & 1098 & 0.20 & - & - & - & - & RI, NIST \\
\hline Linalool & 1097 & 1101 & 0.34 & 0.08 & - & - & - & MS, NIST \\
\hline Nonanal & 1102 & 1105 & - & 0.16 & - & - & - & RI, NIST \\
\hline 2-phenylethanol & 1107 & 1115 & 2.36 & - & 4.65 & - & - & MS, NIST \\
\hline Methyl octanoate & 1127 & 1127 & 0.04 & - & - & - & - & RI, NIST \\
\hline cis-verbenol & 1141 & 1142 & 0.92 & - & - & - & - & RI, NIST \\
\hline trans-verbenol & 1145 & 1148 & 4.60 & - & - & - & - & RI, NIST \\
\hline Camphor & 1150 & 1157 & - & 0.12 & - & - & - & MS, NIST \\
\hline Nonenal & 1162 & 1161 & 0.41 & - & 0.17 & - & - & RI, NIST \\
\hline$\alpha$-phellandren-8-ol & 1170 & 1169 & 2.15 & - & - & - & - & RI, NIST \\
\hline Terpinen-4-ol & 1177 & 1179 & 1.53 & - & - & - & - & RI, NIST \\
\hline Diethyl succinate & 1182 & 1184 & 0.33 & - & - & - & - & RI, NIST \\
\hline p-cymen-8-ol & 1183 & 1186 & 0.29 & - & - & - & - & RI, NIST \\
\hline$\alpha$-terpineol & 1189 & 1192 & 0.18 & - & - & - & 0.28 & RI, NIST \\
\hline
\end{tabular}


Table 1. Cont.

\begin{tabular}{|c|c|c|c|c|c|c|c|c|}
\hline \multirow[b]{2}{*}{ Compound ${ }^{a}$} & \multirow[b]{2}{*}{$\mathbf{R I}^{\mathbf{b}}$} & \multirow[b]{2}{*}{$\mathrm{RI}^{\mathrm{c}}$} & \multirow[b]{2}{*}{$\begin{array}{c}\text { D. chrysotoxum } \\
\%\end{array}$} & \multirow{2}{*}{$\begin{array}{c}\text { Section Dendrobium } \\
\text { D. harvejanum } \\
\%\end{array}$} & \multirow[b]{2}{*}{$\begin{array}{c}\text { D. wardianum } \\
\%\end{array}$} & \multicolumn{2}{|c|}{ Section Densiflora } & \multirow[b]{2}{*}{ Identification $^{\mathrm{d}}$} \\
\hline & & & & & & $\begin{array}{c}\text { D. amabile } \\
\%\end{array}$ & $\begin{array}{c}\text { D. chrysanthum } \\
\%\end{array}$ & \\
\hline Ethyl octanoate & 1196 & 1199 & 0.20 & - & - & - & - & RI, NIST \\
\hline Decanal & 1202 & 1206 & - & - & 0.04 & - & - & RI, NIST \\
\hline Verbenone & 1205 & 1210 & 0.20 & - & - & - & - & MS, NIST \\
\hline 2,4-nonandienal & 1212 & 1214 & - & - & 0.03 & - & - & RI, NIST \\
\hline 4-vinylphenol & 1224 & 1221 & - & - & 0.52 & 0.08 & - & RI, NIST \\
\hline 3-phenyl-1-propanol & 1232 & 1231 & - & - & 0.08 & - & - & RI, NIST \\
\hline Nerol & 1254 & 1256 & 0.06 & - & - & - & - & RI, NIST \\
\hline 2,4-decadienal $(E, E)$ & 1291 & 1295 & 0.40 & 0.39 & 0.39 & 0.16 & - & RI, NIST \\
\hline 2-methoxy-4-vinyl-phenol & 1315 & 1315 & - & - & 0.24 & - & - & RI, NIST \\
\hline 2,4-decadienal $(E, Z)$ & 1319 & 1317 & 0.63 & 0.88 & 0.48 & 0.72 & & RI, NIST \\
\hline 2-nonenoic acid- $\gamma$-lactone & 1345 & 1344 & 0.39 & - & 0.49 & - & - & RI, NIST \\
\hline Capric acid & 1359 & 1359 & - & 0.32 & - & & & RI, NIST \\
\hline Eugenol & 1367 & 1366 & - & - & - & 0.10 & - & RI, NIST \\
\hline 1-tetradecene & 1390 & 1393 & - & 0.07 & - & & 0.57 & MS, RI \\
\hline 3,4-dihydrocoumarin & 1398 & 1399 & - & - & - & 0.10 & - & RI, NIST \\
\hline Ethyl-cinnammate & 1467 & 1468 & - & - & 0.55 & - & - & RI, NIST \\
\hline 2,4-di-tert-butylphenol & 1494 & 1489 & & - & & 0.12 & 22.81 & MS, NIST \\
\hline$\beta$-selinene & 1494 & 1489 & 0.25 & - & 1.30 & - & - & MS, NIST \\
\hline 9-oxo-ethyl-nonanoate & 1507 & 1510 & 1.28 & - & - & - & - & MS, NIST \\
\hline Lauric acid & 1566 & 1568 & 0.23 & - & - & - & - & RI, NIST \\
\hline Ethyl laurate & 1593 & 1596 & 0.15 & - & - & - & - & RI, NIST \\
\hline Unidentified & - & 1658 & - & 5.16 & - & - & - & - \\
\hline Pentadecan-2-one & 1667 & 1667 & - & - & 0.26 & - & - & RI, NIST \\
\hline Heptadecane & 1700 & 1700 & 0.31 & - & 0.54 & - & - & RI, NIST \\
\hline Unidentified & - & 1767 & 0.39 & - & 3.04 & - & - & - \\
\hline Myristic acid & 1780 & 1776 & & - & 3.59 & - & - & MS, NIST \\
\hline 1-octadecene & 1790 & 1796 & 0.32 & - & 0.41 & - & - & MS, RI \\
\hline Methyl pentadecanoate & 1820 & 1828 & 0.04 & - & - & - & - & MS, NIST \\
\hline Unidentified & - & 1879 & 5.74 & - & - & - & - & - \\
\hline Ethyl pentadecanoate & 1890 & 1896 & 0.36 & - & 0.19 & - & - & MS, NIST \\
\hline
\end{tabular}


Table 1. Cont.

\begin{tabular}{|c|c|c|c|c|c|c|c|c|}
\hline \multirow[b]{2}{*}{ Compound ${ }^{a}$} & \multirow[b]{2}{*}{$\mathbf{R I}^{\mathbf{b}}$} & \multirow[b]{2}{*}{ RI $^{c}$} & \multirow[b]{2}{*}{$\begin{array}{c}\text { D. chrysotoxum } \\
\%\end{array}$} & \multirow{2}{*}{$\begin{array}{c}\text { Section Dendrobium } \\
\text { D. harvejanum } \\
\%\end{array}$} & \multirow[b]{2}{*}{$\begin{array}{c}\text { D. wardianum } \\
\%\end{array}$} & \multicolumn{2}{|c|}{ Section Densiflora } & \multirow[b]{2}{*}{ Identification $^{d}$} \\
\hline & & & & & & $\begin{array}{c}\text { D. amabile } \\
\%\end{array}$ & $\begin{array}{c}\text { D. chrysanthum } \\
\%\end{array}$ & \\
\hline Heptadecan-2-one & 1902 & 1903 & 0.11 & - & & - & - & RI, NIST \\
\hline cis-9-hexadecenoic acid & 1942 & 1943 & - & - & - & - & 4.06 & RI, NIST \\
\hline Z-11-Hexadecenoic acid & 1953 & 1953 & - & - & - & - & 29.22 & RI, NIST \\
\hline Palmitic acid & 1958 & 1960 & 0.05 & 7.52 & 5.76 & 0.61 & 13.52 & RI, NIST \\
\hline Neocembrene & 1960 & 1966 & 0.52 & - & 3.07 & - & - & MS, NIST \\
\hline Octadecan-1-ol & 2074 & 2071 & 0.17 & - & 0.60 & - & - & MS, NIST \\
\hline Eicosane & 2000 & 2000 & - & 40.42 & - & - & 0.55 & RI, NIST \\
\hline Unidentified & - & 2037 & - & 2.06 & - & - & & - \\
\hline Methyl linoleate & 2051 & 2068 & 7.48 & 2.50 & 13.17 & - & 1.03 & MS, NIST \\
\hline 10-Heneicosene & 2060 & 2073 & - & - & - & 0.43 & - & MS, RI \\
\hline Heneicosane & 2100 & 2100 & 1.01 & 2.92 & 1.66 & 0.25 & - & RI, NIST \\
\hline Linoleic acid & 2144 & 2147 & 0.12 & - & 17.54 & - & - & RI, NIST \\
\hline Ethyl linolenate & 2169 & 2171 & 26.98 & - & 32.24 & - & - & RI, NIST \\
\hline Ethyl oleate & 2179 & 2181 & 5.39 & - & 0.72 & - & - & RI, NIST \\
\hline Docosane & 2200 & 2204 & 1.66 & 26.82 & - & 1.94 & 17.53 & RI, NIST \\
\hline 9-Triacosene & 2279 & 2275 & 0.31 & - & - & - & - & MS, RI \\
\hline Tricosane & 2300 & 2307 & 9.33 & - & - & - & - & RI, NIST \\
\hline Tetracosane & 2400 & 2401 & 0.40 & 0.90 & - & - & 2.07 & RI, NIST \\
\hline 9-Pentacosene & 2474 & 2475 & 0.07 & & - & - & & MS, RI \\
\hline Pentacosane & 2500 & 2501 & 0.95 & 6.53 & - & - & 6.40 & RI, NIST \\
\hline Hexacosane & 2600 & 2600 & - & 2.46 & - & - & - & RI, NIST \\
\hline 9-Eptacosene & 2676 & 2676 & - & - & - & - & 1.15 & MS, RI \\
\hline Heptacosane & 2700 & 2701 & 0.18 & - & - & - & - & RI, NIST \\
\hline Aldehydes & & & 3.15 & 1.62 & 1.20 & 0.88 & 0.06 & \\
\hline Alcohols & & & 7.97 & 0.12 & 7.02 & 0.30 & 22.81 & \\
\hline Acids & & & 0.45 & 7.84 & 26.89 & 0.61 & 46.80 & \\
\hline Coumarin & & & 0.71 & 0.19 & 0.54 & 95.59 & - & \\
\hline Esters & & & 46.59 & 2.50 & 49.33 & - & 1.03 & \\
\hline Ketones & & & 0.62 & 0.12 & 0.26 & - & 0.68 & \\
\hline
\end{tabular}


Table 1. Cont.

\begin{tabular}{|c|c|c|c|c|c|c|c|c|}
\hline \multirow[b]{2}{*}{ Compound ${ }^{a}$} & \multirow[b]{2}{*}{$\mathbf{R I}^{b}$} & \multirow[b]{2}{*}{$\mathrm{RI}^{\mathrm{c}}$} & \multirow[b]{2}{*}{$\begin{array}{c}\text { D. chrysotoxum } \\
\%\end{array}$} & \multirow{2}{*}{$\begin{array}{c}\text { Section Dendrobium } \\
\text { D. harvejanum } \\
\%\end{array}$} & \multicolumn{4}{|c|}{ Section Densiflora } \\
\hline & & & & & $\begin{array}{c}\text { D. wardianum } \\
\%\end{array}$ & $\begin{array}{c}\text { D. amabile } \\
\%\end{array}$ & $\begin{array}{c}\text { D. chrysanthum } \\
\%\end{array}$ & Identification $^{d}$ \\
\hline Saturated hydrocarbons & & & 22.84 & 80.20 & 2.20 & 2.19 & 26.55 & \\
\hline Terpenes & & & 2.04 & - & 5.73 & - & - & \\
\hline Oxygenated terpenes & & & 8.31 & 0.11 & - & - & 0.34 & \\
\hline Miscellanea & & & 0.48 & - & 0.49 & - & - & \\
\hline Unidentified & & & 6.13 & 7.22 & 5.92 & - & - & \\
\hline
\end{tabular}

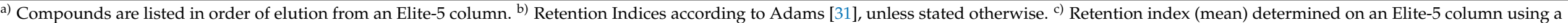
homologous series of $n$-hydrocarbons, d) Method of identification: MS, mass spectrum; NIST, comparison with library [32]; RI, retention indices in agreement with literature values. 


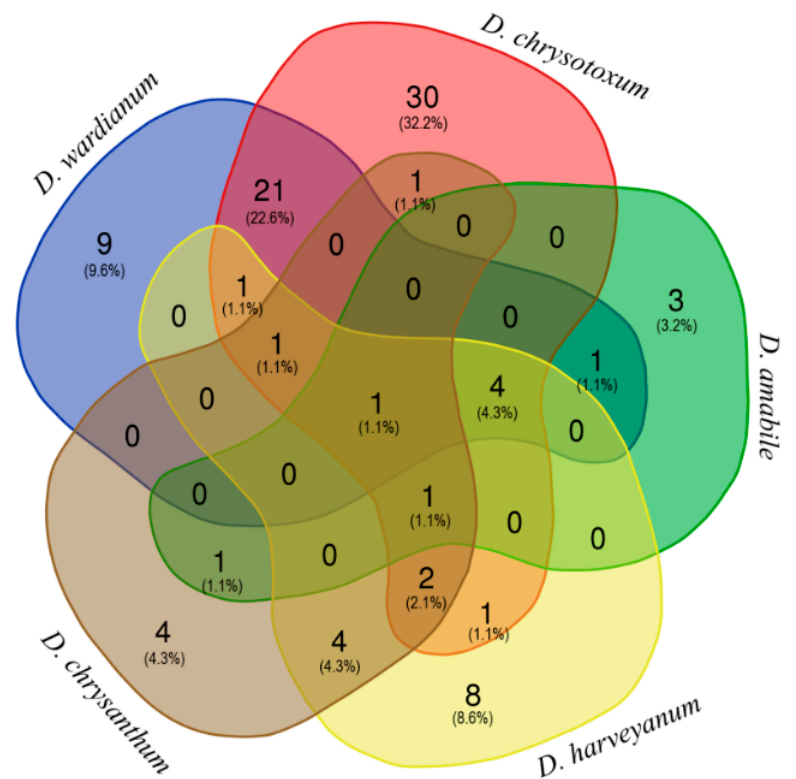

Figure 2. Venn's diagram shows both the number of compounds shared and unshared/peculiar among the five Dendrobium species. Percentages are referred to the total number of compounds found, not to the relative abundance.

D. chrysotoxum

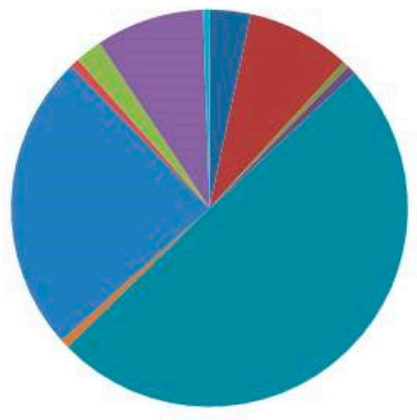

D. amabile

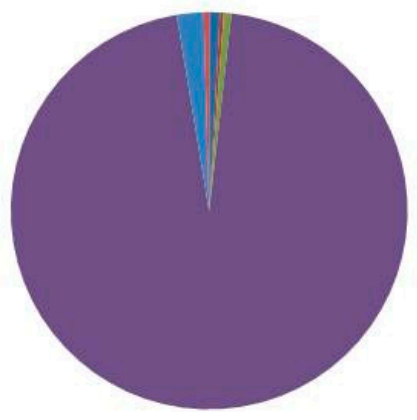

D. harveyanum

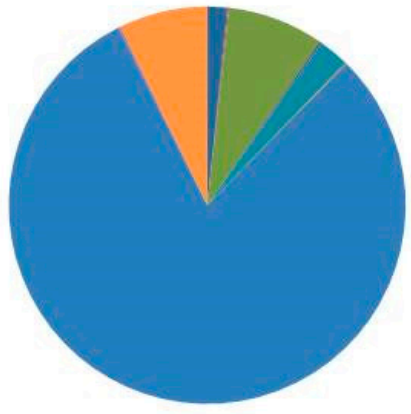

D. chrysanthum

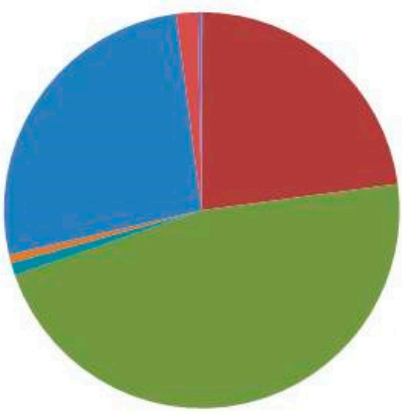

D. wardianum

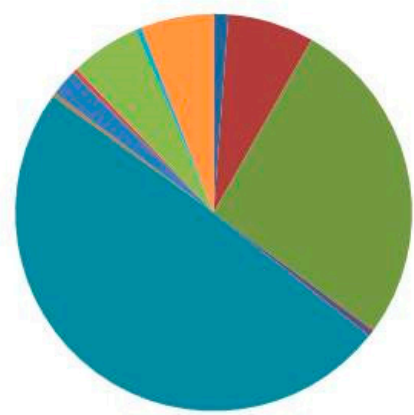

|Aldehydes | Saturated hydrocarbons

| Alcohols || Unsaturated hydrocarbons

$\|$ Acids $\quad \|$ Terpenes

| Coumarin || Oxygenated terpenes

| Esters | Miscellanea

|| Ketones || Unidentified

Figure 3. Pie chart of distribution of the classes.

Dendrobium amabile: The dominant compound was coumarin, accounting for $95.59 \%$ of the total essential oil. Of its derivatives, 3,4-dihydrocoumarin has been detected but in lower amounts $(0.10 \%)$. The second-largest class $(2.19 \%)$ is represented by saturated hydrocarbons, particularly docosane $(1.94 \%)$ and heneicosane $(0.25 \%)$. Aldehydes $(0.88 \%)$ are 
represented by $(E, Z)$-2,4-decadienal and $(E, E)$-2,4-decadienal ( 0.72 and $0.16 \%)$. Unsaturated hydrocarbons are dominated by 10 -heneicosene $(0.43 \%)$.

Dendrobium chrysanthum: The main bulk of constituents is represented by acids accounting for $46.80 \%$ of the total essential oil, from which (Z)-11-hexadecenoic acid (29.22\%), palmitic acid (13.52\%), and (Z)-9-hexadecenoic acid (4.06\%) are the most abundant compounds. The second-largest class is featured by saturated hydrocarbons $(26.55 \%)$ from which docosane $(17.53 \%)$, pentacosane $(6.40 \%)$, and tetracosane $(2.07 \%)$ are the most abundant compounds. Alcohols (22.81\%) are dominated by 2,4-di-tert-butylphenol (22.81\%). Unsaturated hydrocarbons $(1.72 \%)$ are represented by 9 -heptacosene $(1.15 \%)$ and 1-tetradecene $(0.57 \%)$. Esters are represented by methyl linoleate $(1.03 \%)$.

Dendrobium chrysotoxum: The main bulk of constituents is represented by esters $(46.59 \%)$, from which ethyl linolenate $(26.98 \%)$, methyl linoleate $(7.48 \%)$, ethyl oleate $(5.39 \%)$, ethyl palmitate $(3.05 \%)$, and 9-oxo-nonanoic acid, ethyl ester $(9.28 \%)$ are the most abundant compounds. The second-largest class is represented by saturated hydrocarbons, accounting for $22.84 \%$ of the total essential oil, from which heneicosane $(10.01 \%)$, tricosane $(9.33 \%)$, and docosane $(1.66 \%)$ are the most abundant compounds. Oxygenated terpenes $(8.31 \%)$ are dominated by trans-verbenol $(4.60 \%)$, followed by terpinen-4-ol (1.53\%) and cis-verbenol (0.92\%). Alcohols, accounting for $7.97 \%$ of the total essential oil, are featured by 1-octanol (2.80\%), 2-phenylethanol (2.36\%), and $\alpha$-phellandren-8-ol (2.15\%). Aldehydes (3.15\%) are represented by phenylacetaldehyde $(0.84 \%)$, hexanal $(0.73 \%)$, $(E, Z)-2,4$-decadienal $(0.48 \%)$ and $(E, E)$-2,4-decadienal $(0.40 \%)$. Terpenes $(2.04 \%)$ are featured by $\gamma$-terpinene $(0.76 \%)$ and neocembrene $(0.52 \%)$.

Dendrobium harveyanum: The main bulk of constituents is represented by saturated hydrocarbons, accounting for $80.20 \%$ of the total essential oil, from which eicosane $(40.42 \%)$, docosane $(26.82 \%)$, pentacosane $(6.53 \%)$ heneicosane $(2.92 \%)$, and hexacosane $(2.46 \%)$ are the most abundant compounds. The second-largest class is characterized by acids accounting for $7.84 \%$ of the total essential oil. The dominant compound of this class appears to be palmitic acid $(7.52 \%)$. Aldehydes $(1.62 \%)$ are represented by $(E, Z)-2,4$-decadienal $(0.88 \%)$ followed by $(E, E)-2,4$-decadienal $(0.39 \%)$.

Dendrobium wardianum: The main bulk of constituents is represented by esters $(49.33 \%)$ from which ethyl linolenate $(32.24 \%)$, methyl linoleate $(13.17 \%)$, ethyl palmitate $(0.99 \%)$, phenylacetic acid ethyl ester $(0.72 \%)$, ethyl oleate $(0.72 \%)$ and ethyl cinnamate $(0.55 \%)$ are the most abundant compounds. The second-largest class is characterized by acids accounting for $26.89 \%$ of the total essential oil, from which linoleic acid (17.54\%), palmitic acid (5.76\%), and myristic acid (3.59\%) are the most representative compounds. Alcohols, accounting for $7.02 \%$ of the total essential oil are featured by 2 -phenylethanol $(4.65 \%)$, octadecan-1-ol $(0.60 \%)$, 4-vinylphenol (0.52\%), benzyl alcohol (0.52\%) and 2-methoxy-4-vinyl-phenol (0.24\%). Terpenes $(5.73 \%)$ are characterized by neocembrene $(3.07 \%)$, 9-epi-(E)-caryophyllene $(1.32 \%)$ and $\beta$-selinene (1.30\%). Saturated hydrocarbons, accounting for $2.20 \%$ of the total essential oil, are represented by heneicosane $(1.66 \%)$ and heptadecane $(0.54 \%)$. Aldehydes $(1.20 \%)$ are featured by $(E, Z)-2,4$-decadienal and $(E, E)-2,4$-decadienal $(0.48$ and $0.39 \%)$.

\section{Discussion}

Little is known about the pollinators of the studied species, but as argued by Dobson (2006) and Witjes et al. (2011), it is possible to reconstruct the pollinator community behind a certain species by analyzing the volatile composition of flowers $[33,34]$. While research is still needed to identify pollinators, our analyses constitute a first contribution for the study of compounds possibly involved in plant-animal interactions. However, other functions of floral volatiles, that may play a crucial role in herbivory avoidance and as defensive molecules against pathogens, cannot be excluded [35,36]. Differences in the floral scents of related taxa could play a role in reproductive isolation by influencing pollinator's behavior and choices [37-40]. Indeed, in some cases, a simple change in the amount of one floral VOC has been linked with strong reproductive isolation, as seen in Silene dioica (L.) Clairv. and S. latifolia Poir. [41]. However, this ethological type of isolation seems to be more or less 
pivotal depending on the specialization of both the plants and pollinators considered, highlighting the need to carry out additional detailed behavioral experiments to understand plant-pollinator interactions [3].

In this work, the relative composition in floral VOCs of the five Dendrobium species was qualitatively studied. The highest number of species-specific compounds were recorded for entities from section Dendrobium. Palmitic acid was the only compound shared by all the five taxa examined. This molecule is frequently found in the volatilome of several plant species (Orchidaceae included) [23,35,42], and also in other organisms; we observed that it was relatively abundant in D. chrysanthum (13\%), followed by D. harveyanum $(7.52 \%)$ and D. wardianum $(5.76 \%)$, while in the remaining two species it was less represented.

The scent recognized for both $D$. chrysotoxum and $D$. wardianum could be due to the high presence of esters in floral VOCs that we detected during our analyses. Esters are produced by the reaction of alcohols with organic acids; they typically have fruity smells and are indeed among the molecules responsible for the odors of many fruits [43]. High content of volatile esters has been linked with the strong flavor of the "snow chrysanthemum" cultivar of Coreopsis by Kim et al. (2020) [44]. In D. moschatum, a putative role as semiochemicals involved in pollinator attraction has been hypothesized for methyl and ethyl esters by Robustelli della Cuna et al. (2017) [23]. According to da Silva et al. (1999) and Cseke et al. (2007), terpenes are more abundant in flower VOCs of species pollinated by food-seeking bees $[45,46]$. As shown in Table $1, D$. wardianum had the highest level (5.73\%) of terpenes in the essential oil, followed by D. chrysotoxum $(2.04 \%)$, but this class of compounds was not the predominant one in these two species. Conversely, oxygenated terpenes have been detected only in D. chrysotoxum $(8.31 \%)$, while they were present in lower percentages in $D$. harveyanum and $D$. chrysanthum. Therefore, due to their ester and terpenoid contents, and considering similar results obtained by Flath and Ohinata (1982) for $D$. superbum, we cannot exclude that $D$. chrysotoxum and D. wardianum could rely on the action of frugivorous flies or bees, or other animals for their pollination [19].

It is noteworthy that the VOCs spectrum of D. amabile, a scented orchid, was almost entirely dominated by coumarin, a compound having a sweet smell that resembles vanilla. On the contrary, this compound was present only in very small percentages in all the other Dendrobiums considered. As previously stated by Robustelli della Cuna et al. 2017, coumarin was abundant, although less represented in respect to D. amabile, also in VOCs from inflorescences and leaves of D. moschatum [23]. In this species, authors hypothesized a phytoalexin-like defensive role for coumarin. In the future, a possible role of coumarin in plant-pollinator interactions should be investigated. Interestingly, D. chrysanthum showed a distinctive floral volatile composition compared to the other species. Indeed, this entity displayed the highest amounts of acids (accounting for $46.8 \%$ of the total essential oil), together with a good representation of alcohols $(22.8 \%)$ if compared to the other species considered. Among acids, the most representative one (29.2\%) was Z-11-Hexadecenoic acid, a known sex pheromone in moths [47]. Considering the relatively high content of this compound, we can again hypothesize its possible role as pollinator (putatively, moth) attractant. Concerning alcohols, 2,4-di-tert-butylphenol was relatively abundant in D. chrysanthum. This molecule was also present in traces in D. amabile. Zhang et al. (2017) and Huang et al. (2018) recorded the occurrence of this alcohol in flowers of D. moniliforme (L.) Sw. and rhizomes of Gastrodia elata Blume, respectively [48,49]. This compound, known for its toxicity, exerts several bioactivities and has insecticidal, nematicidal, antibacterial, and antifungal properties (Zhao et al., 2020 and references therein) [50]. Therefore, a defensive role for 2,4-di-tert-butylphenol in D. chrysanthum cannot be excluded. Finally, it is interesting to notice that among the Dendrobium and Densiflora sections, three self-incompatible species, $D$. amabile and D. harveyanum, and D. chrysanthum, respectively, showed a reduced spectrum of volatiles [51,52]. It is tempting to hypothesize that this has a role in pollination biology; indeed, discouraging pollinators from pollinating more flowers of the same plant and inducing pollinators to visit different individuals, would result in a higher fruit set. 


\section{Conclusions}

In conclusion, this is the first study reporting the floral volatile components of D. amabile, D. chrysanthum, D. chrysotoxum, D. harveyanum, and D. wardianum. Our results can put the basis for the investigation of Dendrobium's pollination biology and plantherbivore interactions, but further studies to find the pollinators and understand their behaviors are required for deciphering the role of the compounds detected in these five Dendrobium species. Considering the present results, studies on the fingerprint of the essential oils of other Dendrobium sections (i.e., Calcarifera, Crumenata, Fugacia, Latouria, and Spatulata) are in progress in our lab.

\section{Materials and Methods}

\subsection{Plant Material}

All examined species were provided by specialized sellers, in details: $D$. wardianum (Buchanan-Hamilton) Swartz, D. chrysotoxum (Lindley) and D. harveyanum (Rchb.f.) from Orchid's and more, (Ismaning, Germany), D. amabile (O'Brien) and D. chrysanthum (Wallich ex Lindley) from Kopf Orchideen und Floristik, (Deggendorf, Germany). Plants were identified according to Dressler (2016) [53], and cultivated under intermediate greenhouse conditions at the University of Turin, Italy, for two years before analyses. Plants were grown in intermediate conditions in a greenhouse during winter months and outside from April to October using a bark well-drained potting medium. Samples were collected at the flowering stage and stored at $-20^{\circ} \mathrm{C}$ until extraction. Before extraction, the flowers were brought back to room temperature and subjected to steam distillation.

\subsection{Isolation of the Essential Oil}

Flowers (D. amabile $25 \mathrm{~g}$, D. chrysanthum $5.53 \mathrm{~g}$, D. chrysotoxum $5.87 \mathrm{~g}$, D. harveyanum $6.14 \mathrm{~g}$, D. wardianum 6.26 g), to which octyl octanoate ( $98 \%$, Sigma-Aldrich, Inc., St. Louis, MO, USA) was added as internal standard, were steam distilled with odor-free water for $3 \mathrm{~h}$. The distillate was extracted with methylene chloride $(3 \times 100 \mathrm{~mL})$ (Merck, Darmstadt, Germany), dried over anhydrous sodium sulfate (Sigma-Aldrich, Inc., St. Louis, MO, USA), and concentrated at first with a rotary evaporator and subsequently using a gentle stream of $\mathrm{N}_{2}$ for successive GC/FID and GC/MS analyses [23,36].

\subsection{GC-FID Analysis}

The analyses were carried out using a Hewlett Packard model 5980 GC, equipped with Elite-5MS ( $5 \%$ phenyl methyl polysiloxane) capillary column of $(30 \mathrm{~m} \times 0.32 \mathrm{~mm}$ i.d.) and film $0.32 \mu \mathrm{m}$ thick. The carrier gas was He at a flow of $1 \mathrm{~mL} / \mathrm{min}$. One $\mu \mathrm{L}$ aliquots of essential oil were manually injected in splitless mode. The oven temperature program included an initial isotherm of $40{ }^{\circ} \mathrm{C}$ for $5 \mathrm{~min}$, followed by a temperature ramp to $260{ }^{\circ} \mathrm{C}$ at $4{ }^{\circ} \mathrm{C} / \mathrm{min}$, and a final isotherm at this temperature for $10 \mathrm{~min}$. Injector and detector temperatures were set at 250 and $280^{\circ} \mathrm{C}$, respectively. The relative amount of each component was calculated based on the corresponding FID peak area without response factor correction.

\subsection{GC-MS Analysis}

The analyses were carried out using a GC Model 6890 N, coupled to a benchtop MS Agilent 5973 Network, equipped with the same capillary column and following the same chromatographic conditions used for the GC/FID analyses. The carrier gas was $\mathrm{He}$ at a constant flow of $1.0 \mathrm{~mL} / \mathrm{min}$. The essential oils were diluted before analysis, and $1.0 \mu \mathrm{L}$ was manually injected into the GC system with a split ratio of 30:1. The ion source temperature was set at $200{ }^{\circ} \mathrm{C}$, while the transfer line was at $300^{\circ} \mathrm{C}$. The acquisition range was 40-500 amu in electron-impact (EI) positive ionization mode using an ionization voltage of $70 \mathrm{eV}$. 


\subsection{Identification and Quantification of the Essential Oil Components}

The identification of the volatile oil components was performed by their retention indices (RI) and their mass spectra [31], and by comparison with a NIST database mass spectral library, as well as with literature data [32,54]. Retention indices were calculated by Elite-5MS capillary columns using an n-alkane series $\left(\mathrm{C}_{6}-\mathrm{C}_{35}\right)$ (Sigma-Aldrich, Inc., St. Louis, MO, USA) under the same GC conditions as for samples. The relative amount of each component of the oil was expressed as percent peak area relative to total peak area from GC/FID analyses of the whole extracts. The quantitative data were obtained from GC/FID analyses by an internal standard method and assuming an equal response factor for all detected compounds.

Author Contributions: Conceptualization, F.S.R.d.C. and J.C.; methodology and investigation, F.S.R.d.C., M.B. and J.C.; writing-original draft preparation, F.S.R.d.C., M.B., J.C. and S.P.; writingreview and editing, C.S. and E.G.; supervision, J.C. All authors have read and agreed to the published version of the manuscript.

Funding: This research received no external funding.

Institutional Review Board Statement: Not applicable.

Informed Consent Statement: Not applicable.

Data Availability Statement: Not applicable.

Conflicts of Interest: The authors declare no conflict of interest.

\section{References}

1. Kaiser, R. The Scent of Orchids: Olfactory and Chemical Investigations; Elsevier: Amsterdam, The Netherlands, 1993.

2. Ramya, M.; Jang, S.; An, H.R.; Lee, S.Y.; Park, P.M.; Park, P.H. Volatile organic compounds from orchids: From synthesis and function to gene regulation. Int. J. Mol. Sci. 2020, 21, 1160. [CrossRef]

3. Schiestl, F.P.; Schlüter, P.M. Floral isolation, specialized pollination, and pollinator behavior in orchids. Annu. Rev. Entomol. 2009, 54, 425-446. [CrossRef] [PubMed]

4. Takamiya, T.; Wongsawad, P.; Sathapattayanon, A.; Tajima, N.; Suzuki, S.; Kitamura, S.; Shioda, N.; Handa, T.; Kitanaka, S.; Iijima, H.; et al. Molecular phylogenetics and character evolution of morphologically diverse groups, Dendrobium section Dendrobium and allies. AoB Plants 2014, 6, plu045. [CrossRef] [PubMed]

5. Hinsley, A.; de Boer, H.J.; Fay, M.F.; Gale, S.W.; Gardiner, L.M.; Gunasekara, R.S.; Kumar, P.; Masters, S.; Metusala, D.; Roberts, D.L.; et al. A review of the trade in orchids and its implications for conservation. Bot. J. Linn. Soc. 2018, 186, 435-455. [CrossRef]

6. Teoh, E.S. Medicinal Orchids of Asia; Springer: Berlin/Heidelberg, Germany, 2016.

7. Cheng, J.; Dang, P.; Zhao, Z.; Yuan, L.; Zhou, Z.; Wolf, D.; Luo, Y. An assessment of the Chinese medicinal Dendrobium industry: Supply, demand and sustainability. J. Ethnopharmacol. 2018, 229, 81-88. [CrossRef]

8. Adams, P. Systematics of Dendrobiinae (Orchidaceae), with special reference to Australian taxa. Bot. J. Linn. Soc. 2011, 166, 105-126. [CrossRef]

9. Xiang, X.G.; Schuiteman, A.; Li, D.Z.; Huang, W.C.; Chung, S.W.; Jianwu, L.; Zhou, H.L.; Jin, W.T.; Lai, Y.; Li, Z.Y.; et al. Molecular systematics of Dendrobium (Orchidaceae, Dendrobieae) from mainland Asia based on plastid and nuclear sequences. Mol. Phylogenet. Evol. 2013, 69, 950-960. [CrossRef]

10. Stern, W.L.; Curry, K.J.; Whitten, W.M. Staining fragrance glands in orchid flowers. Bull. Torrey Bot. Club. 1986, $113,288-297$. [CrossRef]

11. Yukawa, T. Chloroplast DNA Phylogeny and Character Evolution of the Subtribe Dendrobiinae (Orchidaceae). Ph.D. Thesis, Chiba University, Chiba, Japan, 1993.

12. Martin, K.P.; Madassery, J. Rapid in vitro propagation of Dendrobium hybrids through direct shoot formation from foliar explants, and protocorm-like bodies. Sci. Hortic. 2006, 108, 95-99. [CrossRef]

13. Teixeira da Silva, J.; Cardoso, J.; Dobránszki, J.; Zeng, S. Dendrobium micropropagation: A review. Plant Cell Rep. 2015, 34, 671-704. [CrossRef]

14. Calevo, J.; Copetta, A.; Marchioni, I.; Bazzicalupo, M.; Pianta, M.; Shirmohammadi, N.; Cornara, L.; Giovannini, A. The use of a new culture medium and organic supplement to improve in vitro early stage development of five orchid species. Plant Biosyst. Int. J. Deal. All Asp. Plant Biol. 2020. [CrossRef]

15. Carlsward, B.S.; Stern, W.; Judd, W.S.; Lucansky, T. Comparative leaf anatomy and systematics in Dendrobium, Sections Aporum and Rhizobium (Orchidaceae). Int. J. Plant Sci. 1997, 158, 332-342. [CrossRef] 
16. Xu, J.; Han, Q.B.; Li, S.L.; Chen, X.J.; Wang, X.N.; Zhao, Z.Z.; Chen, H. Chemistry, bioactivity and quality control of Dendrobium, a commonly used tonic herb in traditional Chinese medicine. Phytochem. Rev. 2013, 12, 341-367. [CrossRef]

17. Devadas, R.; Pattanayak, S.; Singh, D.R. Studies on cross compatibility in Dendrobium species and hybrids. Indian J. Genet. Plant Breed. 2016, 76, 344-355. [CrossRef]

18. Shen, X.Y.; Liu, C.G.; Pan, K. Reproductive biological characteristics of Dendrobium species. In Reproductive Biology of Plants, CRC: Boca Raton, FL, USA, 2014. [CrossRef]

19. Flath, R.A.; Ohinata, K. Volatile components of the orchid Dendrobium superbum Rchb. f. J. Agric. Food Chem. 1982, 30, 841-842. [CrossRef]

20. Brodmann, J.; Twele, R.; Francke, W.; Yi-bo, L.; Xi-qiang, S.; Ayasse, M. Orchid mimics honey bee alarm pheromone in order to attract hornets for pollination. Curr. Biol. 2009, 19, 1368-1372. [CrossRef]

21. Silva, R.; Uekane, T.M.; Rezende, C.M.; Bizzo, H.R. Floral volatile profile of Dendrobium nobile (Orchidaceae) in circadian cycle by dynamic headspace in vivo: Brazilian Symposium on Essential Oils. In Proceedings of the 8-International Symposium on Essential Oils, Rio de Janeiro, Brazil, 10-13 November 2015.

22. Julsrigival, J.; Songsak, T.; Kirdmanee, C.; Chansakaow, S. Determination of volatile constituents of Thai fragrant orchids by gas chromatography-mass spectrometry with solid-phase microextraction. Chiang Mai Univ. J. Nat. Sci. 2013, 12. [CrossRef]

23. Robustelli della Cuna, F.S.; Boselli, C.; Papetti, A.; Calevo, J.; Mannucci, B.; Tava, A. Composition of volatile fraction from inflorescences and leaves of Dendrobium moschatum (Orchidaceae). Nat. Prod. Commun. 2017, 13, 93-96. [CrossRef]

24. Kjellsson, G.; Rasmussen, F.N. Does the pollination of Dendrobium unicum Seidenf. involve pseudopollen? Orchidee 1987, 34, 183-187.

25. Inoue, K.; Kato, M.; Inoue, T. Pollination ecology of Dendrobium setifolium, Neuwiedia borneensis, and Lecanorchis multiflora (Orchidaceae) in Sarawak. Tropics 1995, 5, 95-100. [CrossRef]

26. Davies, K.; Turner, M. Pseudopollen in Dendrobium unicum Seidenf. (Orchidaceae): Reward or deception? Ann. Bot. 2004, 94, 129-132. [CrossRef] [PubMed]

27. Kamińska, M.; Stpiczyńska, M. The structure of the spur nectary in Dendrobium finisterrae Schltr. (Dendrobiinae, Orchidaceae). Acta Agrobot. 2011, 64, 19-26. [CrossRef]

28. Pang, S.; Pan, K.; Wang, Y.J.; Li, W.; Zhang, L.; Chen, Q.B. Floral morphology and reproductive biology of Dendrobium jiajiangense (Orchidaceae) in Mt. Fotang, southwestern China. Flora Morphol. Distrib. Funct. Ecol. Plants 2012, 207, 469-474. [CrossRef]

29. Slater, A.; Calder, D. The pollination biology of Dendrobium speciosum Smith: A case of false advertising? Aust. J. Bot. 1988, 36, 145-158. [CrossRef]

30. Kjellsson, G.; Rasmussen, F.N.; Dupuy, D. Pollination of Dendrobium infundibulum, Cymbidium insigne (Orchidaceae) and Rhododendron lyi (Ericaceae) by Bombus eximius (Apidae) in Thailand: A possible case of floral mimicry. J. Trop. Ecol. 1985, 1, 289-302. [CrossRef]

31. Adams, R. Identification of Essential Oil Components by Gas Chromatography/Mass Spectrometry, 4th ed.; Allured Publishing Corporation: Carol Stream, IL, USA, 2007.

32. Stein, S.E. NIST/EPA/NIH Mass Spectral Database; Version 2.1; Perkin-Elmer Instrument LLC: Waltham, MA, USA, 2000.

33. Dobson, H.E.M. Relationship between floral fragrance composition and type of pollinator. In Biology of Floral Scent; Dudareva, N., Pichersky, E., Eds.; CRC Press: Boca Raton, FL, USA, 2006; p. 147.

34. Witjes, S.; Witsch, K.; Eltz, T. Reconstructing the pollinator community and predicting seed set from hydrocarbon footprints on flowers. Oecologia 2011, 166, 161-174. [CrossRef] [PubMed]

35. Knudsen, J.T.; Eriksson, R.; Gershenzon, J.; Ståhl, B. Diversity and distribution of floral scent. Bot. Rev. 2006, 72, 1-20. [CrossRef]

36. Robustelli della Cuna, F.S.; Calevo, J.; Bari, E.; Giovannini, A.; Boselli, C.; Tava, A. Characterization and antioxidant activity of essential oil of four sympatric orchid species. Molecules 2019, 24, 3878. [CrossRef] [PubMed]

37. Knudsen, J.T.; Tollsten, L. Trends in floral scent chemistry in pollination syndromes. Floral scent composition in moth-pollinated taxa. Bot. J. Linn. Soc. 1993, 113, 263-284. [CrossRef]

38. Raguso, R.A. Floral Scent, Olfaction, and Scent-Driven Foraging Behavior, in Cognitive Ecology of Pollination; Chittka, L., Thomson, J.D., Eds.; Cambridge University Press: Cambridge, UK, 2001; p. 83.

39. Ayasse, M.; Stokl, J.; Francke, W. Chemical ecology and pollinator-driven speciation in sexually deceptive orchids. Phytochemistry 2011, 72, 1667-1677. [CrossRef]

40. Pellegrino, G.; Luca, A.; Bellusci, F.; Musacchio, A. Comparative analysis of floral scents in four sympatric species of Serapias L. (Orchidaceae): Clues on their pollination strategies. Plant Syst. Evol. 2012, 298, 1837-1843. [CrossRef]

41. Arnold, S.E.J.; Forbes, S.J.; Hall, D.R.; Farman, D.I.; Bridgemohan, P.; Spinelli, G.R.; Bray, D.P.; Perry, G.B.; Grey, L.; Belmain, S.R.; et al. Floral odors and the interaction between pollinating Ceratopogonid midges and Cacao. J. Chem. Ecol. 2019, 45, 869-878. [CrossRef] [PubMed]

42. Waelti, M.O.; Muhlemann, K.; Widmer, A.; Schiestl, F.P. Floral odour and reproductive isolation in two species of Silene. J. Evol. Biol. 2008, 21, 111-121. [CrossRef]

43. Hu, J.; Huang, W.; Zhang, F.; Luo, X.; Chen, Y.; Xie, J. Variability of volatile compounds in the medicinal plant Dendrobium officinale from different regions. Molecules 2020, 25, 5046. [CrossRef] [PubMed]

44. Kim, B.R.; Kim, H.M.; Jin, C.H.; Kang, S.Y.; Kim, J.B.; Jeon, Y.G.; Park, K.Y.; Lee, I.S.; Han, A.R. Composition and antioxidant activities of volatile organic compounds in radiation-bred Coreopsis cultivars. Plants 2020, 9, 717. [CrossRef] 
45. Da Silva, U.F.; Borba, E.L.; Semir, J.; Marsaioli, A. A simple solid injection device for the analyses of Bulbophyllum (Orchidaceae) volatiles. Phytochemistry 1999, 50, 31-34. [CrossRef]

46. Cseke, L.J.; Kaufman, P.B.; Kirakosyan, A. The biology of essential oils in the pollination of flowers. Nat. Prod. Commun. 2007, 2, 1317-1336. [CrossRef]

47. Xia, Y.H.; Ding, B.J.; Wang, H.L.; Hofvander, P.; Jarl-Sunesson, C.; Löfstedt, C. Production of moth sex pheromone precursors in Nicotiana spp.: A worthwhile new approach to pest control. J. Pest. Sci. 2020, 93, 1333-1346. [CrossRef]

48. Zhang, C.; Liu, S.J.; Yang, L.; Hu, J.M. Determination of volatile components from flowers of Dendrobium moniliforme (L.) Sw. in Yunnan by GC-MS. J. Yunnan Agric. Univ. 2017, 32, 174-178.

49. Huang, M.Z.; Li, X. Kind and content of volatile components in Gastrodia elata by SDE-GC-MS analysis. Guizhou Agric. Sci. 2018, $46,110-113$

50. Zhao, F.; Wang, P.; Lucardi, R.D.; Su, Z.; Li, S. Natural sources and bioactivities of 2,4-di-tert-butylphenol and its analogs. Toxins 2020, 12, 35. [CrossRef] [PubMed]

51. Niu, S.C.; Huang, J.; Xu, Q.; Li, P.X.; Yang, H.J.; Zhang, Y.Q.; Zhang, G.Q.; Chen, L.J.; Niu, Y.X.; Luo, Y.B.; et al. Morphological type identification of self-incompatibility in Dendrobium and its phylogenetic evolution pattern. Int. J. Mol. Sci. 2018, 19, 2595. [CrossRef] [PubMed]

52. Wang, Q.; Shao, S.; Su, Y.; Hu, X.; Shen, Y.; Zhao, D. A novel case of autogamy and cleistogamy in Dendrobium wangliangii: A rare orchid distributed in the dry-hot valley. Ecol. Evol. 2019, 9, 12906-12914. [CrossRef] [PubMed]

53. Dressler, R.L. Phylogeny and Classification of the Orchid Family; Dioscorides Press: Portland, OR, USA, 1993.

54. Joulain, D.; Konig, W.A. The Atlas of Spectral Data of Sesquiterpene Hydrocarbons; E. B. Verlag: Hamburg, Germany, 1998. 